\title{
SIGNIFICANCE OF LEGUMES AS A FEED SOURCE
}

Liga Proskina ${ }^{1}$, Dr.oec.; Irina Pilvere ${ }^{1}$, Dr.oec.

${ }^{1}$ Faculty of Economics and Social Development, Latvia University of Life Sciences and Technologies

\begin{abstract}
The European Union faces a challenge to increase the production of domestic protein crops in order to lower its economic dependence on imports of protein crops, soybeans in particular, and the fluctuation of global prices on food. To solve the problem of self-sufficiency of protein in the EU, encompassing all the agro-climatic zones typical of European agriculture and all-level supply chains at the EU level, increasing the output of domestic protein crops, including legumes (faba beans, peas, lupine, soybeans etc.) has been set as a strategic goal. The research examined the kinds of protein crops used for feed and the self-sufficiency of the crops in the EU. The research examined the area under legumes for seeds, the yields and the protein yields of the crops in Latvia. The research aim is to examine the key characteristics of production of feed legumes in Latvia. To achieve the aim, the following specific research tasks are defined: 1) to examine the characteristics of production of protein feed crops in the EU Member States; 2) to analyse legume production performance indictors in Latvia.
\end{abstract}

Key words: protein feed, legumes, indicators.

JEL code: Q22.

\section{Introduction}

European livestock production systems must face the challenge to meet world animal products demands. According to FAO Food Balance data (FAO, 2019), global food consumption considerably increased in recent decades; at the same time, global food demand rose on average by $1.7 \%$ annually (OECD - FAO, 2018). This contributes to livestock production intensification and an increase in the demand for feed, incl. high protein content feed (Westhoek et al., 2011). The demand for protein feed of plant origin is increased by the restriction imposed by Regulation (EC) No 999/2001 to use animal protein in feed to avoid the risk of spongiform encephalopathy as well as the limitation of EU support to oilseeds following the Blair House Agreement in 1992.

In Europe and Latvia, food of animal origin accounts for approximately $45 \%$ of the total value of agricultural output (Westhoek et al., 2011). Accordingly, a regular and guaranteed supply of feed plays a large role in the competitiveness of the EU livestock industry. Despite the high proportion of livestock production, the EU Member States face a deficit of domestically produced feed protein for their livestock industries (FEFAC, 2018; DG AGRI, 2018), which is offset by imports from third countries. In accordance with Regulation (EC) No. 178/2002, requirements for the production, labelling, traceability and control of feed have been designed and integrated into the relevant legal frameworks of the Member States. However, the same legal restrictions in the areas of the environment, health and GMO do not apply to imported protein crops produced outside the EU as they do in the case of products manufactured in the EU. At the same time, the trends in the world market show that the prices of protein-rich feed rose (DG AGRI, 2018), thereby considerably affecting the overall feed price level and therefore livestock production cost. Agricultural trade statistical data indicate that in recent ten years, the prices of protein feedstuffs have constantly risen. In the recent decade, the average price of soybean flour on commodity exchanges fluctuated from EUR 223 to 519 per tonne, reaching EUR 317 per tonne at the end of 2018. The price on soybean flour imported from the USA rose from EUR 215 per tonne in 2007 to EUR 380 per tonne in 2018 (DG AGRI, 2018; IndexMundi, 2019). Overall, the prices on imported soybeans, rapeseed and sunflower flour rose by 43-65\% in this period. In 2018, the price of domestic feed-grade wheat in the ES-28 was on average EUR 191, in Latvia - EUR 180 per tonne. A the end of 2018, the prices of feed-grade peas and beans

${ }^{1}$ Contacts Tel. : +371 28206624 
in the EU was on average $219 \mathrm{EUR} / \mathrm{t}$ and $240 \mathrm{EUR} / \mathrm{t}$, respectively, while in Latvia the prices of the pulses was on average $198 \mathrm{EUR} / \mathrm{t}$ and $202 \mathrm{EUR} / \mathrm{t}$ (DG AGRI, 2018).

In recent years in many countries research investigations into protein sources have been conducted, as a high protein content feedstuff is the most expensive component of a feed ration. The need for cheaper protein-rich feedstuffs has been referred to in a number of research studies owing to the problem of the high proportion of feed cost (Czulowska and Zekalo, 2016). A lower production cost can be achieved if using domestic products - cereals as a source of nutritional energy and faba beans and peas as a source of protein - in animal feed. It has to be emphasised that providing farming with domestic feed ensures higher independence of the agricultural industry from feed price fluctuations in the world market and sustainable use of the agricultural area.

The current agricultural intensification is oriented towards high productivity and is characterised by narrow specialisation (Emmerson et al., 2016), thereby contributing to a considerable decrease in the diversity of crops in the EU, which leads to a decrease in the area under legumes (Watson and Stoddard, 2017). At present, food-grade wheat and rapeseed dominate in the output of crops, while high-quality protein crops needed for livestock production are imported from third countries. Such an approach to agricultural production has negatively affected the self-sufficiency of feed protein as well as contributed to the degradation of ecosystems in the EU Member States.

Thus, the EU faces a challenge to increase the production of domestic protein crops in order to lower its economic dependence on imports of soybeans and the fluctuation of global prices on food. To solve the problem of self-sufficiency of protein in the EU, encompassing all the agro-climatic zones typical of European agriculture and all-level supply chains - local, regional, national and EU level -, increasing the output of soybeans and other protein crops, including legumes (faba beans, peas, lupine, soybeans etc.) and papilionaceous crops (alfalfa), as well as recognising sunflower and rapeseed meal as an important component of feed have been set as a strategic goal.

The EU Common Agricultural Policy (CAP) focuses on sustainable agricultural development. To achieve this goal, according to Davis et al. (2012), it is required to promote the diversification of crops. Zander et al. (2016) point out that the inclusion of legumes in crop rotation increases the economic efficiency of grain production, lowering the cost of agricultural chemicals by $20-25 \%$ if the grains are grown as the aftercrop (Zander et al., 2016). Watson and Stoddard (2017) stress that the regional (domestic) production of legumes reduces greenhouse gas (GHG) emissions, increases the diversity of crops in crop production systems, contribute to biodiversity, enhance soil fertility and supply the livestock industry with protein sources of domestic origin (Watson and Stoddard, 2017). Crotty et al. (2018) point out that legume forages are fundamental in the development of sustainable livestock systems, building soil fertility and providing local protein for ruminant livestock (Crotty et al., 2018).

Livestock farming have built up experience in using legumes - in diets for pigs and poultry dried seeds (pulses) as a component of feed concentrate, in diets for ruminants in the form of both legume forage and pulses. However, a large role in the supply of feed protein is played particularly by legume seeds (pulses) and crops used mainly for oil extraction (e.g. soybean, rapeseed). The United Nations Food and Agriculture Organization (FAO) recognizes 11 types of pulses grown worldwide. Pulses are a type of leguminous crop that are harvested solely for the dry seed. Pulses do not include other feeds in the legume family, such as crops used mainly for oil extraction (e.g. soybean and groundnuts) and leguminous crops that are used exclusively for sowing purposes (e.g. seeds of clover and alfalfa). Historically, the use of pulses in animal feeds has been limited due to the presence of 
antinutritional factors (Sherasia, Garg and Bhanderi, 2017), yet, recent advances in plant breeding have helped to reduce the presence of the factors. When pulses were introduced as a protein feedstuff in diets for animals, new varieties were created, which had with low-tannin, low vicine-convicine and low-trypsin inhibitor contents. Smith et al. (2013) indicates that pulses have been suggested as an alternative protein source to soybean for livestock in Europe (Smith et al., 2013). Therefore, it is required to identify the situation in the production of protein feed crops in the EU and the prospects for this industry along with conventional protein crops used in livestock production.

The research aim is to examine the key characteristics of production of feed legumes in Latvia. To achieve the aim, the following specific research tasks are defined: 1) to analyse legume production performance indictors in Latvia; 2 ) to examine the characteristics of production of protein feed crops in the EU Member States. The research examined the kinds of protein feed crops and the output of the crops in the EU. It also focused on the area under protein crops, including legumes, as well as the yields and the protein yields of pulses in Latvia.

Methodology and data. Analysis, synthesis, logical and construction, induction and deduction were employed to execute the research tasks. Scientific literature review was used as well.

\section{Research results and discussion}

\section{Areas and yields of pulses and protein crops}

At the EU level, political discussions have focused on the production of protein of plant origin and the agricultural and food industries, issues related to domestic inputs, particularly the use of domestic protein crops as feed as well as the sustainable preservation of soil fertility, with a special focus on growing papilionaceous crops and legumes. As the EU CAP 2014-2020 prescribed that each Member State has to allocate $2 \%$ of its support payments for growing protein crops, interest in the production of protein crops, incl. legumes, increased, and the area under protein crops significantly expanded. In 2017 compared with the period before the CAP reform (2012), the area under soybeans in the EU doubled and reached almost a million hectares; besides, the area under legumes also increased (EUROSTAT, 2018). In the neighbouring countries - Lithuania and Estonia - the areas under legumes and protein crops increased 6-fold in the same period and reached 236.2 and 65.5 thousand ha, respectively (Figure 1 ). In this period in Latvia, the area under protein crops increased as well.

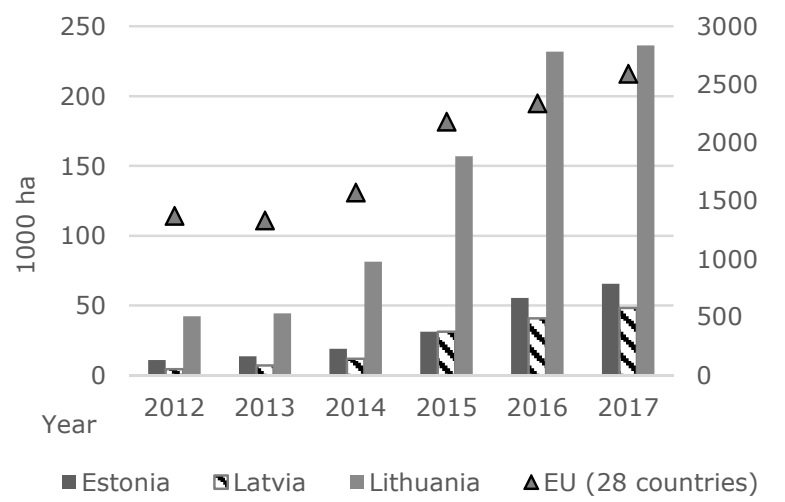

Source: (EUROSTAT, 2018)

Fig. 1. Areas under legumes and protein crops (for the production of grain, including seed and mixtures of cereals and pulses), 1000 ha

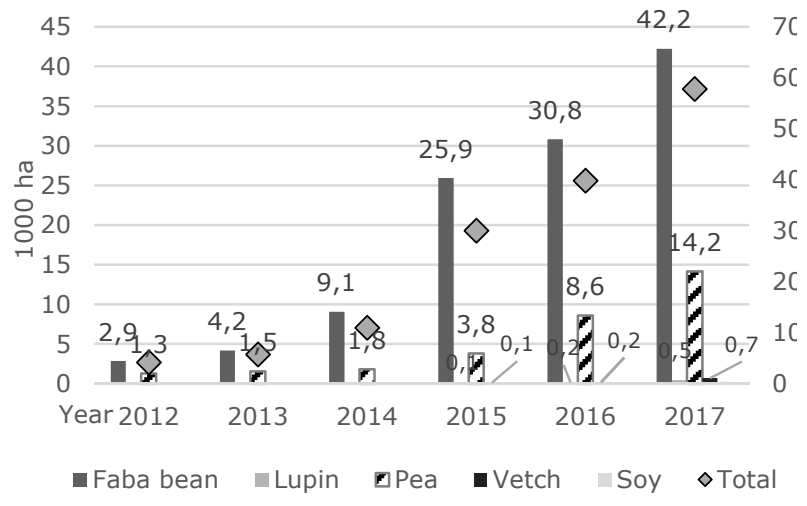

Source: (RSS, 2019)

Fig. 2. Areas cropped with legumes in Latvia in 2012-2018, 1000 ha

In the period 2012-2017, the total area under faba beans rose about 13.7 times (from 2.9 thousand ha to 42.2 thousand ha). The two main kinds of legumes grown in Latvia are peas and faba beans (Figure 2), some legume species such as lupine, vetch and soybeans are cultivated in Latvia 
rarely or not at all. The area under peas increased 10 times (from 1.3 thousand ha to 14.2 thousand ha); the area sown with less known feed legumes - lupines - rose about 5 times (from 80 ha to 480 ha) $(R S S, 2019)$. Such a fast increase in the area under legumes was promoted by the EU's policy on the protection and improvement of biodiversity on farms (Regulation (EU) No. 1307/2013), yet it is not enough to reduce the deficit of feed protein.

Table 1

Yields of pulses and the crude protein content thereof in Latvia in 2015-2017

\begin{tabular}{|c|c|c|c|c|c|c|c|c|c|c|c|c|c|c|}
\hline \multirow{2}{*}{$\begin{array}{c}\text { Feed } \\
\text { materia } \\
\text { l/ } \\
\text { Year }\end{array}$} & \multicolumn{3}{|c|}{$\begin{array}{c}\text { Average yield, } \\
\text { t ha }\end{array}$} & \multicolumn{3}{|c|}{$\begin{array}{c}\text { Total yield, } \\
1000 t\end{array}$} & \multicolumn{2}{|c|}{$\begin{array}{c}\text { Protein } \\
\text { content, } \\
\mathrm{kg} \mathrm{t}^{-1}\end{array}$} & \multicolumn{3}{|c|}{$\begin{array}{c}\text { Protein yield, } \\
\text { t ha }\end{array}$} & \multicolumn{3}{|c|}{$\underset{\mathbf{t}}{\text { Total protein yield, }}$} \\
\hline & 2015 & 2016 & 2017 & 2015 & 2016 & 2017 & $\min$ & $\max$ & 2015 & 2016 & 2017 & 2015 & 2016 & 2017 \\
\hline Pea & 3 & 2.6 & 2.1 & 11.8 & 23.1 & 29.5 & 198 & 230 & 0.65 & 0.56 & 0.45 & 2537 & 4967 & 6343 \\
\hline $\begin{array}{l}\text { Faba } \\
\text { bean }\end{array}$ & 3.4 & 3.2 & 3.3 & 86.8 & 100.3 & 140.7 & 224 & 333 & 0.73 & 0.97 & 1.00 & 26344 & 30441 & 42702 \\
\hline Lupin & 1.1 & 1.4 & 0.4 & 0.2 & 0.30 & 0.20 & 300 & 430 & 0.24 & 0.51 & 0.13 & 73 & 110 & 73 \\
\hline Soy* & 0.68 & 1.61 & 1.21 & 0.07 & 0.07 & 0.26 & 288 & 337 & 0.21 & 0.50 & 0.38 & 21 & 21 & 83 \\
\hline
\end{tabular}

In Latvia, faba beans and peas are the most significant legumes grown for seeds. Of the total area cropped with legumes, 96-98 \% was regularly harvested. An exception was the year 2017 when only $68 \%$ of the area under peas and $89 \%$ of the area under faba beans were harvested (CSB, 2019), which could be explained by rainfalls and floods that hindered harvesting the crops. In 20152017 in Latvia, the average yields for faba beans was 2.6-2.1 $\mathrm{t} \mathrm{ha-}^{-1}$ and 3.2-3.1 $\mathrm{t} \mathrm{ha-}^{-1}$ for feed peas (Table 1).

The yields of pulses are determined by a number of factors: species, variety, climatic conditions as well as soil management quality. As regards legumes, some research studies state that the diversity of legume species and varieties is determined by the possibilities to grow them in vast climatic regions (Zander et al., 2016). Zimmer et al. (2016) explain the low proportion of the soybean area in the total area under protein crops in the EU by unfavourable climatic conditions for this crop in most of Europe (Zimmer et al., 2016). The data on the yields and crude protein contents of legumes grown in Latvia shown in Table 1 reveal that the highest protein yield per ha was produced by faba beans - in the range of $730-1000 \mathrm{~kg} / \mathrm{ha}$ and peas - 450-650 kg/ha. Experience in growing soybeans is small in Latvia, which is proved by the data, as the protein yield of soybeans was only 210-500 kg/ha.

According to the authors' calculations, the area under both faba beans and peas declared for Rural Support Service (RSS) support payments in 2017 can produce about 48 thousand tonnes of crude protein for feed, which is only a small share of the necessary annual amount of crude protein for livestock farming. For example, approximately 120 thousand tonnes of crude protein were necessary for dairy cows (producing $1 \mathrm{~kg}$ of milk requires 100-140 g of crude protein) to produce the quantity of milk, as stated in the Report on Latvia's Agricultural and Rural Development 2017 (1000 thousand tonnes). It should be emphasized that an increasing area cropped with pulses in Latvia can increase the proportion of domestically produced protein-rich feedstuffs, reduce protein feed imports and contribute to more efficient production.

\section{Supply of protein feed crops in the European Union}

In the EU, the consumption of feed annually increased. In the period 2015-2017, the total consumption of feed rose from 477 to 489 mln.t, of which $48 \%$ were forages, $32.7 \%$ industrial 
compound feed, $10.8 \%$ home-grown cereals and $8.3 \%$ purchased feeding stuffs (FEFAC, 2018). The quantity of protein crops produced provided approximately $27 \mathrm{mln}$. $\mathrm{t}$ of crude protein needed for feed (DG AGRI, 2018), of which 34-35 \% was used in pig production, $24-28 \%$ in poultry, $14-18 \%$ in milk and beef cattle production (Hou et al., 2016).

To meet the demand for feed protein, the EU annually imports about $17 \mathrm{mln}$. $\mathrm{t}$ of crude protein, of which $13 \mathrm{mln}$. t comes from soybeans. An analysis of the self-sufficiency of crude protein reveals that a deficit is observed across almost all the categories of feedstuffs, yet the deficit considerably varies by kind of feed material (Table 2).

Table 2

Self-sufficiency for protein-rich feed materials in the EU-28 in 2016/2017

\begin{tabular}{|c|c|c|c|c|c|c|}
\hline Feed material & $\begin{array}{c}\text { EU } \\
\text { production } \\
(\mathrm{mln} . \mathrm{t})\end{array}$ & $\begin{array}{c}\text { EU total } \\
\text { feed use } \\
\text { (min.t) }\end{array}$ & $\begin{array}{c}\text { EU feed use } \\
\text { of EU origin } \\
(\mathrm{mln} . t)\end{array}$ & $\begin{array}{c}\text { EU total feed } \\
\text { use (mIn.t } \\
\text { proteins) }\end{array}$ & $\begin{array}{c}\text { EU feed use } \\
\text { of EU origin } \\
\text { (mln. } t \\
\text { proteins) }\end{array}$ & $\begin{array}{c}\text { Self- } \\
\text { sufficiency } \\
\text { of protein } \\
(\%)\end{array}$ \\
\hline Cereals & 254.10 & 146.40 & 130.80 & 14.10 & 12.76 & 90 \\
\hline Pulses & 4.40 & 3.00 & 2.80 & 0.77 & 0.71 & 92 \\
\hline Oilseeds & 31.00 & 1.80 & 1.80 & 0.50 & 0.50 & 100 \\
\hline Soybean meal & 1.60 & 29.00 & 1.50 & 13.37 & 0.67 & 5 \\
\hline $\begin{array}{l}\text { Rapeseed } \\
\text { meal }\end{array}$ & 10.90 & 13.20 & 10.40 & 4.36 & 3.43 & 79 \\
\hline $\begin{array}{l}\text { Sunflower } \\
\text { meal }\end{array}$ & 3.90 & 7.70 & 3.60 & 2.43 & 1.02 & 42 \\
\hline
\end{tabular}

Source: DG AGRI, 2018

In the EU, most of the sources of feed protein are represented by grain $(130.8 \mathrm{mln}$. $\mathrm{t}$ of grain or $14 \mathrm{mln}$. $\mathrm{t}$ of crude protein) with the self-sufficiency rate of $90 \%$, yet the rate for the second largest feed material - soybeans - is only $5 \%$ (29 mln. t of soybeans or $13.37 \mathrm{mln}$. $t$ of crude protein). It is known that soybeans represent a valuable component of feed mixtures, which is due to the high protein content (more than $40 \%$ ) and a balanced content of amiNo acids, yet the available research investigations indicate that also pulses contain moderately high levels of protein, and their amiNo acid profiles are generally comparable to that of soybean meals (Hanbury and Hughes, 2003; Nalle, 2009). Therefore, pulses can partly replace soybean protein, yet to date their use as feed has been insignificant - only $3 \mathrm{mln}$. t or $2 \%$ of the total feed protein consumed (Table 2).

As intensification in the livestock industry increased, the output and consumption of industrial compound feed and protein feedstuffs rose as well. The market of industrial compound feed is convincingly the largest market of feed protein, yet it faces serious challenges in relation to the supply of inputs. To produce industrial compound feed, about a third of feed inputs are imported mostly oil crop seeds and flour (incl. soybean) as well as by-products of the food and bioethanol industries (Table 3 ). 
Industrial feed material consumption and imports in the EU-28, 2015-2017

\begin{tabular}{|l|c|c|c|c|c|c|c|c|}
\hline \multirow{2}{*}{$\begin{array}{c}\text { Feed } \\
\text { material } \\
\text { Year }\end{array}$} & \multicolumn{3}{|c|}{$\begin{array}{c}\text { Feed material } \\
\text { consumption, 1000 t }\end{array}$} & Proportion, \% & \multicolumn{2}{c|}{$\begin{array}{c}\text { Feed material } \\
\text { imports, } \\
\text { 1000 t }\end{array}$} & $\begin{array}{c}\text { Imports as \% } \\
\text { of } \\
\text { consumption, }\end{array}$ \\
\cline { 2 - 9 } & 2015 & 2016 & 2017 & 2017 & 2015 & 2016 & 2017 & 2017 \\
\hline Feed cereals & 75063 & 78049 & 79877 & 54.3 & 10700 & 12850 & 14600 & 18.3 \\
\hline $\begin{array}{l}\text { Co-products } \\
\text { from food } \\
\text { and } \\
\text { bioethanol } \\
\text { industry }\end{array}$ & 17221 & 17157 & 18559 & 12.6 & 3962 & 4056 & 4499 & 24.2 \\
\hline $\begin{array}{l}\text { Oilcakes } \\
\text { and Meals }\end{array}$ & 42769 & 41616 & 41251 & 28.0 & 25844 & 24425 & 25358 & 61.5 \\
\hline Pulses & 2114 & 2259 & 2273 & 1.5 & 165 & 200 & 349 & 15.4 \\
\hline Others & 4962 & 4845 & 5117 & 3.5 & 2272 & 2414 & 2318 & 45.3 \\
\hline Total & 142129 & 143926 & 147077 & 100 & 42943 & 43945 & 47124 & 32.0 \\
\hline
\end{tabular}

Source: FEFAC, 2018

As shown in Table 3, soybean flour contributes to $38 \%$ of the total supply of protein (Table 2), while oil crop seeds and flour (incl. soybean) account for $28 \%$ of the total amount of inputs needed in the production of industrial compound feed (Table 3); besides, most of them are imported. To reduce the large imports of feed protein, it is necessary to promote the domestic production of protein crops, as stated by the European Commission communication (COM(2018) 757 final) on the development of plant proteins in the European Union. In industrial compound feed, pulses make up only $1.5 \%$ of the total amount of protein crops.

According to available research studies, such pulses as faba beans and peas are highly productive crops and their economic role is large. Seeds of faba beans and peas are prime quality feed concentrate for poultry and agricultural animals (Koivunen et al., 2016; Sherasia, Garg and Bhanderi, 2017; Harouna, Kawe and Mohammed, 2018), as they comprise 22-35\% protein (Nalle, 2009). An important feed quality indicator for ruminants is soluble protein that can produce the necessary amiNo acids in the organism one hour after the intake of feed. According to the results of tests done at the LLU Scientific Laboratory of Agronomic Analysis, a soluble protein content in the dry matter of faba beans grown in Latvia was, on average, $15.0 \%, 12.5 \%$ in peas and only $3.5 \%$ in soybeans (Osmane et al., 2016). This means that protein-rich feed comprising peas and beans is better digested in the animal organism and can raise economic returns from feedstuffs in farming, i.e. higher productivity at lower or the same resource cost. According to research investigations, an optimum share of pulses in diets for animals of various species is estimated at 15-30\% (Nalle, 2009; Volpelli et al., 2012). This means that the use capacity of pulses allows considerably increasing the amount of pulses in diets and the self-sufficiency of protein in the European Union.

Overall, two thirds of industrial compound feed in the EU-28 is used in poultry production (34\%) and pig production (32\%) and slightly more (28\%) in cattle production (incl. sheep, goats) (Table 4). In Latvia, industrial compound feed is mainly used in poultry production (58\%) and in cattle and pig production, $18 \%$ and $19 \%$, respectively. In the analysis period in Latvia, the output of compound feed for poultry significantly rose (by $17 \%$ ), which could be explained by increases in the output of eggs (14\%) and poultry meat (13\%). In contrast, the output of compound feed for pigs decreased by $22 \%$, and stagnation was observed in the output of feed for cattle, with a trend to remain at the same level. 


\section{Industrial compound feed production in the EU-28 and Latvia in 2015-2017,} mln.t

\begin{tabular}{|l|r|r|r|c|r|r|r|c|}
\hline \multirow{2}{*}{ Indicators } & \multicolumn{3}{|c|}{ EU-28, mIn.t } & \multirow{2}{*}{ 2017/2015, \% } & \multicolumn{3}{|c|}{ Latvia, mIn.t } & \multirow{2}{*}{ 2017/2015, \% } \\
\cline { 2 - 5 } & 2015 & 2016 & 2017 & & 2015 & 2016 & 2017 & \\
\hline Cattle & 42500 & 43213 & 44937 & 5.73 & 57 & 55 & 64 & 12.28 \\
\hline Pigs & 50436 & 50310 & 51302 & 1.72 & 85 & 73 & 66 & -22.35 \\
\hline Poultry & 52887 & 54360 & 54807 & 3.63 & 173 & 178 & 202 & 16.76 \\
\hline Others & 9191 & 8915 & 9086 & -1.14 & 11 & 9 & 14 & 27.27 \\
\hline TOTAL & 155014 & 156798 & 160132 & 3.30 & 326 & 315 & 346 & 6.13 \\
\hline
\end{tabular}

Source: FEFAC, 2018

Poultry and pig feed mainly consists of maize, wheat and soybean flour; therefore, any increase in the price of cereals and protein feedstuffs in the world market undoubtedly influence the production cost of poultry meat. In Latvia, poultry enterprises provide the necessary amount of protein in feed, including broiler chicken feed, by means of mainly imported crude protein-rich feedstuffs. They are: feed yeast, soya, sunflower meals, maize flour etc. According to an analysis of production costs, the cost of feed is the key component, yet, a detailed analysis of production costs indicates that the highest proportion of production costs relates to imported feed and its components. For this reason, opportunities for the use of domestically grown protein crops for feed have to be assessed in order to minimise the cost of diets for agricultural animals and poultry.

\section{Conclusions, proposals, recommendations}

1) The key sources of feed protein are grain, soybean flour and rapeseed flour. In the period 20162017, the consumption of protein by the livestock industry totalled $27 \mathrm{mln}$. $\mathrm{t}$, of which $17 \mathrm{mln}$. were imported. Most of the imports were comprised of soybeans - $13 \mathrm{mln}$. $\mathrm{t}$ of crude protein, which was comparable to 25-30 mln. t of soybeans.

2) Pulses are little used as feed, making up only $2 \%$ of the total feed protein and $1.5 \%$ of the total industrial compound feed consumed. Research investigations into the use of pulses as feed showed that an optimum share of pulses in diets for animals of various species was estimated at 15-30\%. This means that the use capacity of pulses could be increased at least 10-fold.

3) An increase in the area under protein crops was promoted by the EU's policy on the protection and improvement of biodiversity on farms (Regulation (EU) No. 1307/2013). Overall, the area sown with protein crops in the EU-28 under the CAP reform increased on average 2-fold, yet the self-sufficiency of the crops was insufficient. In Latvia, the area under protein crops (legumes) increased on average 12-fold.

4) Faba beans and peas were the most significant protein feed crops produced in Latvia. The highest protein yield per ha was produced by faba beans - in the range of $730-1000 \mathrm{~kg} / \mathrm{ha}$ and peas 450-650 kg/ha. Experience in growing soybeans is small in Latvia, and the protein yield of soybeans was only $210-500 \mathrm{~kg} / \mathrm{ha}$.

\section{Acknowledgements}

The research received funding from the ERDF Post-doctoral Research Support Programme (project No.1.1.1.2/16/I/001) Research application „Assessment of the Bioeconomic Efficiency of Use of Legumes for Feed" (No.1.1.1.2./VIAA/1/16/181).

\section{Bibliography}

1. Crotty, F. V. et al. (2018). Increasing Legume Forage Productivity through Slurry Application - a Way to Intensify Sustainable Agriculture?, Food and Energy Security, 7(4). doi: 10.1002/fes3.144. 
2. CSB (2019). Central Statistical Bureau of Latvia. Databases. Agriculture, Forestry and Fisheries. Retrieved: https://www.csb.gov.Iv/lv/statistika/db.

3. Czułowska, M. and Żekało, M. (2016). The Impact of Commercial Concentrated Feedingstuffs Usage on the Profitability of Milk Production Wpływ żywienia przemysłowymi paszami treściwymi na opłacalność produkcji mleka', Journal of Central European Agriculture, 17(1), pp. 75-85. doi: 10.5513/JCEA01/17.1.1674.

4. Davis, A. S. et al. (2012). 'Increasing Cropping System Diversity Balances Productivity, Profitability and Environmental Health', PLOS ONE. Edited by J. p. Hart, 7(10), p. e47149. doi: 10.1371/journal. pone.0047149.

5. DG AGRI (2018) Analysis. Statistics. Retrieved: https://ec.europa.eu/agriculture/statistics_en.

6. Emmerson, M. et al. (2016). How Agricultural Intensification Affects Biodiversity and Ecosystem Services, Advances in Ecological Research. Academic Press, 55, pp. 43-97. doi: 10.1016/BS.AECR.2016.08.005.

7. EUROSTAT (2018) EUROSTAT Data. Database. Retrieved: https://ec.europa.eu/eurostat/data/database.

8. FAO (2019) Statistics. Databases. Retrieved: http://www.fao.org/economic/ess/ess-home/en/. Access: 20.01.2019.

9. FEFAC (2018) The European Feed Manufacturers' Federation (FEFAC ). Publications. Retrieved: https://www.fefac.eu/our-publications/statistics/ Access: 18.02.2019.

10. Hanbury, C. and Hughes, B. (2003) Lathyrus Cicera as Quality Feed for Laying Hens, Lathyrus Lathyrism Newsl.

11. Harouna, D. V., Kawe, p. C. and Mohammed, E. M. I. (2018). Under-Utilized Legumes as Potential Poultry Feed Ingredients: A Mini- Review', 1(1), pp. 1-3. Retrieved: https://juniperpublishers.com/onlinesubmission.php. Access: 12.02.2019.

12. Hou, Y. et al. (2016). Feed Use and Nitrogen Excretion of Livestock in EU-27', Agriculture, Ecosystems \& Environment, 218, pp. 232-244. doi: 10.1016/j.agee.2015.11.025.

13.IndexMundi (2019) Commodity Prices. Available at: https://www.indexmundi.com/commodities/. Access: 12.01.2019.

14. Koivunen, E. et al. (2016). Digestibility and Energy Value of Pea (Pisum sativum L.), Faba Bean (Vicia faba L.) and Blue Lupin (narrow-leaf) (Lupinus angustifolius) Seeds in Broilers, Animal Feed Science and Technology. Elsevier, 218, pp. 120-127. doi: 10.1016/J.ANIFEEDSCI.2016.05.007.

15. Nalle, C. L. (2009). Nutritional Evaluation of Grain Legumes for Poultry. Massey University, Palmerston North, New Zealand. Retrieved: https://mro.massey.ac.nz/bitstream/handle/10179/1021/02whole.pdf?sequence=1\&isAllowed=y. Accessed: 12.02.2019.

16. OECD - FAO (2018) OECD-FAO Agricultural Outlook $2018 \square 2027$ Special focus: Middle East and North Africa, OECD-FAO Agricultural Outlook 2018-2027. Paris/FAO, Rome. doi: 10.1787/agr-outl-data-en.

17. Osmane, B. et al. (2016). Chemical Composition of Various Pea and Bean Varieties Grown in Latvia, Engineering for Rural Development, pp. 262-267.

18. RSS (2019). Rural Support Service of the Republic of Latvia. Area Payments. (In Latvian). Available at: http://lad.gov.Iv/Iv/statistika/platibu-maksajumi/.

19. Sherasia, p. L., Garg, M. R. and Bhanderi, B. M. (2017). Pulse and their by-Products as Animal Feed. Edited by T. Calles and H. p. S. Makkar. Rome: FAO. Retrieved: http://www.fao.org/3/a-i7779e.pdf. Access: 21.02.2019.

20.Smith, L. A. et al. (2013). Effects of Dietary Inclusion of Pea and Faba Bean as a Replacement for Soybean Meal on Grower and Finisher Pig Performance and Carcass Quality, Journal of Animal Science, 91(8), pp. 3733-3741. doi: 10.2527/jas.2012-6157.

21. Volpelli, L. A. et al. (2012). Pea (Pisum Sativum) and Faba Beans (Vicia faba) in Dairy Cow Diet: Effect on Milk Production and Quality, Italian Journal of Animal Science, 11(2), pp. 217-222. doi: 10.4081/ijas.2012.e40.

22. Watson, C. A. and Stoddard, F. L. (2017). Introduction - Perspectives on Legume production and Use in European Agriculture', Legumes in Cropping Systems, pp. 1-17.

23. Westhoek, H. et al. (2011). The Consumption and Production of Meat, Dairy and Fish in the European Union, The protein puzzle.

24.Zander, p. et al. (2016). Grain Legume Decline and Potential Recovery in European Agriculture: a Review. Agronomy for Sustainable Development, Agron. Sustain. Dev. Springer Verlag/EDP Sciences/INRA, 36(2), p. 26. doi: 10.1007/s13593-016-0365-y.

25.Zimmer, S. et al. (2016). Effects of Soybean Variety and Bradyrhizobium Strains on Yield, Protein Content and Biological Nitrogen Fixation under Cool Growing Conditions in Germany, European Journal of Agronomy. doi: 10.1016/j.eja.2015.09.008. 